\title{
PENGARUH PEMBERIAN EKSTRAK TEMU PUTIH (Curcuma zedoaria (Berg.) Roscoe) TERHADAP KADAR ENZIM LDH TIKUS PUTIH (Rattus norvegicus) YANG DIINDUKSI ASAP ROKOK
}

\author{
Mu'minnisa Bahrun, Sukamto S. Mamada, Subehan Lallo, Sumarheni \\ Fakultas Farmasi, Universitas Hasanuddin, Makassar
}

Kata Kunci :

Asap rokok, Curcuma zedoaria (Berg)

Roscoe, Laktat

Dehidrogenase (LDH)

\begin{abstract}
ABSTRAK
Partikel-partikel asap rokok diketahui mengandung tingkat radikal bebas tinggi yang dapat menyebabkan kerusakan atau kematian sel organ-organ di dalam tubuh. Peningkatan enzim Laktat dehidrogenase ( $\mathrm{LDH}$ ) dapat digunakan sebagai biomarker pada saat terjadi kerusakan atau kematian sel tersebut. Penelitian ini bertujuan untuk mengetahui efek terapi dari ekstrak temu putih (ETP) terhadap kadar enzim LDH tikus (Rattus norvegicus) yang diinduksi asap rokok. Sebanyak 12 ekor tikus diinduksi asap rokok selama 30 menit dengan menggunakan 10 batang rokok perhari kemudian diberikan vitamin C dosis $100 \mathrm{mg} / \mathrm{ml}$ sebagai kontrol positif, ETP dengan dosis $70 \mathrm{mg} / 200 \mathrm{gBB}$ dan dosis $105 \mathrm{mg} / 200 \mathrm{gBB}$. Penginduksian dilakukan selama 30 hari kemudian dilakukan pengambilan sampel darah. Pengukuran kadar enzim LDH menggunakan reagen kit diagnostik pada instrument ABX Pentra 400. Uji Oneway ANOVA menunjukkan bahwa pemberian ETP secara peroral pada hewan coba tikus menunjukkan penurunan kadar LDH pada setiap dosis yang digunakan yaitu $70 \mathrm{mg} / 200 \mathrm{gBB}$ dan $105 \mathrm{mg} / 200 \mathrm{gBB}$ dengan perbedaan secara nyata dibandingkan kelompok kontrol negatif $(p<0,05)$. Sehingga dapat disimpulkan bahwa ETP dosis $70 \mathrm{mg} / 200 \mathrm{gBB}$ dan 105mg/200gBB memberikan efek terapi dengan menurunkan kadar enzim LDH pada tikus yang diinduksi asap rokok.
\end{abstract}

\section{PENDAHULUAN}

Laktat dehidrogenase (LDH) adalah enzim sitoplasmatik yang terdapat pada hampir semua sistem organ utama tubuh. Aktivitas utama enzim ini adalah mengkatalisis konversi asam laktat menjadi asam piruvat dan sebaliknya, dalam proses metabolisme glukosa $(1,2)$. Meskipun kurang spesifik, namun peningkatan enzim LDH dapat digunakan sebagai biomarker pada saat terjadi kerusakan atau kematian sel. Pelepasan enzim LDH ke pembuluh darah dapat ditemukan pada kondisi iskemia, kelebihan panas atau dingin, kelaparan, dehidrasi, cedera, paparan racun bakteri maupun setelah menelan obat-obatan tertentu, atau keracunan senyawa kimia $(3,4,5)$.

Salah satu kebiasaan atau gaya hidup yang dapat menyebabkan kerusakan atau kematian sel dalam tubuh yaitu merokok. Data Riset Kesehatan Dasar (Riskesdas) tahun 2013 menunjukkan bahwa prevalensi perokok di Indonesia meningkat menjadi 36,3\% dan sekitar 75\% masih merokok di dalam rumah bersama anggota keluarga yang lain. Oleh karena itu, terdapat lebih dari 97 juta orang Indonesia yang tidak merokok terkena paparan asap rokok dan dapat membunuh setidaknya 225.000 orang setiap tahunnya (6). Asap rokok dapat merusak hampir semua organ di dalam tubuh dan Sifat sitotoksisitas dari asap rokok menyebabkan penyakit kronis yang mematikan. Sebuah penelitian yang dilakukan oleh Rodgman dan Perfetti (2009) menyatakan bahwa terdapat lebih dari 5000 komponen kimia pada tembakau. 93 bahan kimia yang dalam rokok berbahaya bagi manusia $(7,8)$. Hal ini dibuktikan dengan tes sitotoksisitas in vitro seperti uji viabilitas sel serta uji kerusakan sel yang menunjukkan bahwa asap rokok dan konstituennya menyebabkan efek toksik yang luas dalam kultur sel maupun jaringan. Partikel-partikel asap rokok mengandung tingkat radikal bebas yang tinggi atau potensi oksidatifnya sangat kuat yang menghasilkan kerusakan sel termasuk kerusakan integritas sel, stress oksidatif, peradangan maupun kerusakan DNA, RNA, lipid dan protein $(9,10,11)$.

Antioksidan dapat memperbaiki sel-sel yang rusak dengan cara menetralisir radikal bebas penyebab penyakit kronis atau kanker. Berdasarkan penelitian yang dilakukan oleh Seifried HE et al (2007) antioksidan telah dianggap sebagai terapi yang menjanjikan untuk pencegahan dan penanganan kondisi stres oksidatif yang dipicu oleh peningkatan ROS. Salah satu tanaman yang berpotensi memiliki aktivitas antioksidan yaitu Curcuma zedoaria dari famili Zingiberaceae. Curcuma zedoaria atau temu putih telah digunakan secara tradisional sebagai antimikroba, antialergi, antiinflamasi, dan antinyeri (12). Beberapa studi menunjukkan bahwa senyawa golongan fenolik yang terdapat dalam Curcuma zedoaria yaitu kurkumin memiliki aktivitas antioksidan yang sangat baik $(13,14,15)$. Penelitian yang dilakukan oleh Saetung et al (2004) menunjukkan bahwa IC50 ekstrak etanol temu putih yaitu $6,05 \mu \mathrm{g} / \mathrm{ml}$ dan $55,50 \mu \mathrm{g} / \mathrm{ml}$ masing-masing terhadap sel kanker paru dan sel normal yang berarti berpotensi tinggi melawan perkembangan sel kanker tetapi relatif aman pada sel normal. Penelitian ini juga telah menentukan bahwa nilai LD50 ekstrak temu putih sebesar $1000 \mathrm{mg} / \mathrm{kgBB}$. Pemberian ekstrak etanol rimpang temu putih pada dosis $500 \mathrm{mg} / \mathrm{kgBB}$ dan 
dosis $750 \mathrm{mg} / \mathrm{kgBB}$ mampu menghambat proses karsinogenesis pada hewan coba mencit dengan persentase masing-masing 73,33\% dan 77,78\% (16). Dengan demikian pemberian ekstrak temu putih diperkirakan dapat mencegah dan mengatasi kerusakan atau kematian sel akibat paparan asap rokok yang diamati berdasarkan perubahan kadar enzim LDH darah.

\section{METODE PENELITIAN}

\section{Preparasi Ekstrak Temu Putih (ETP)}

Sampel rimpang temu putih diambil dari Kabupaten Sidrap, Provinsi Sulawesi Selatan, kemudian dideterminasi di Laboratorium Biologi, Fakultas MIPA Universitas Negeri Makassar.

Pembuatan simplisia rimpang temu putih yang akan digunakan dalam proses ekstraksi dilakukan dengan cara, rimpang disortasi basah lalu dicuci dengan air mengalir, diiris tipis dengan ketebalan 3-5 mm lalu ditimbang sebanyak 500 g-1000 g, selanjutnya dikeringkan dengan menggunakan oven simplisia pada suhu $40^{\circ}-60^{\circ} \mathrm{C}$.

Simplisia rimpang temu putih selanjutnya digiling lalu diayak menggunakan ayakan nomor 18 hingga diperoleh serbuk kasar, dilanjutkan dengan proses ekstraksi, yaitu metode maserasi atau perendaman dengan pelarut etanol 70\%, satu bagian serbuk simplisia (300 g) dalam 10 bagian pelarut. Sebelum dilakukan perendaman, simplisia dibasahi terlebih dahulu menggunakan pelarut etanol $70 \%$ hingga terbasahi sempurna kemudian ditambahkan sisa pelarut. Proses maserasi dilakukan selama 1 hari sambil sesekali diaduk. Maserat disaring dengan kain saring kemudian dilakukan remaserasi sebanyak 2 kali dengan pelarut yang sama selama 2 hari. Ekstrak cair yang didapatkan kemudian ditampung, selanjutnya dilakukan proses pemekatan dengan menggunakan rotary evaporator dan dilanjutkan pengeringan dengan desikator sampai diperoleh ekstrak kental (17).

\section{Pemberian Dosis Ekstrak Temu Putih (ETP)}

Dosis ETP yang diberikan untuk mencit yaitu $500 \mathrm{mg} / \mathrm{kgBB}$ dan $750 \mathrm{mg} / \mathrm{kgBB}$ (18). Dosis tersebut dikonversikan kedalam dosis untuk hewan coba tikus, sehingga didapatkan dosis $70 \mathrm{mg} / 200 \mathrm{gBB}$ tikus dan $105 \mathrm{mg} / 200 \mathrm{gBB}$ tikus. ETP diberikan dalam bentuk suspensi $7 \%$ dan $10,5 \%$ secara p.o.

\section{Penggunaan Hewan Coba}

Kelayakan etik penelitian penggunaan hewan coba ini mendapat persetujuan di Komisi Etik Fakultas Kedokteran Universitas Hasanuddin dengan No. Surat 373/H4.8.4.5.31/PP36-KOMETIK/2018 (lampiran 4). Hewan coba yang akan digunakan adalah tikus putih (Rattus norvegicus) sebanyak 12 ekor dengan bobot badan berkisar 150-250 g ditempatkan di dalam kandang dengan asupan makanan dan air setiap harinya secara ad libitum. Sebelum dilakukan penelitian tikus diadaptasikan selama 7 hari.

Kelompok 1 merupakan kelompok kontrol negatif dengan pemaparan asap rokok dan pemberian larutan koloidal NaCMC 1\%. Kelompok 2 merupakan kelompok kontrol positif, yaitu pemberian pemaparan asap rokok dan pemberian vitamin $\mathrm{C}$ dan NaCMC 1\%. Kelompok 3 merupakan kelompok pemberian pemaparan asap rokok dan ETP 70 mg/200gBB. Kelompok 4 merupakan kelompok pemberian pemaparan asap rokok dan ETP $105 \mathrm{mg} / 200 \mathrm{gBB}$.

Pemberian NaCMC, ETP, dan vitamin C diberikan secara per oral. Perlakuan hewan coba dilakukan selama 30 hari.

\section{Pemaparan Asap Rokok}

Pemberian induksi asap rokok pada hewan coba dilakukan didalam smoking chamber, sesuai prosedur penelitian yang dilakukan Sugeng et al (2010), dengan modifikasi ukuran smoking chamber yaitu 50 x 60 x 40 cm (19). Rokok merek ' $\mathrm{X}$ ' yang dipaparkan pada hewan coba merupakan rokok kretek tanpa filter dan mengandung $39 \mathrm{mg}$ tar dan 2,5 mg nikotin. Tikus dipaparkan asap rokok setiap hari sebanyak 10 batang rokok selama kurang lebih 30 menit. Pemaparan asap rokok diberikan selama 30 hari berturut-turut.

\section{Evaluasi Kadar Enzim LDH}

Sebelum diberi perlakuan, pada hari ke-0 darah diambil terlebih dahulu melalui vena lateral pada ekor tikus untuk dijadikan sebagai kadar enzim LDH awal rikus. Selama perlakuan dilakukan, bobot badan tikus ditimbang secara berkala dan dilakukan pengecekan setiap hari. Setelah itu, darah kemudian diambil kembali melalui vena lateral pada ekor tikus untuk diukur kadar enzim LDH akhir tikus pada hari ke-30. Pegukuran kadar enzim LDH dilakukan dengan menggunakan reagen diagnostic dan instrument $A B X$ pentra 400 .

\section{Analisis Statistik}

Data yang telah diperoleh dianalisis menggunakan software SPSS 20 dengan metode Kolmogorov-sminov untuk melihat distribusi normal data. Data yang terdistribusi normal, dilanjutkan dengan metode analisis one-way ANOVA kemudian dilanjutkan dengan uji post hoc menggunakan uji signifikansi $L S D$. $P$-value $<0,05$ dinyatakan signifikan secara statistic.

\section{HASIL DAN PEMBAHASAN}

Serbuk simplisia rimpang temu putih (Curcuma zedoaria (Berg.) Roscoe) sebanyak 300 gram diekstraksi menggunakan metode maserasi dengan pelarut etanol 70\%. Maserat yang diperoleh selanjutnya dipekatkan menggunakan rotary vacuum evaporator dan disimpan di dalam desikator hingga diperoleh hasil seperti pada Tabel 1.

\begin{tabular}{cc} 
Tabel 1. Hasil Ekstraksi Temu Putih (Curcuma zedoaria (Berg.) Roscoe) \\
\hline Bobot Simplisia (gram) & 300 \\
\hline Bobot Ekstrak (gram) & 82,3825 \\
\hline Rendamen Ekstrak (\%) & 27,461 \\
\hline Organoleptis & $\begin{array}{c}\text { Ekstrak kental, berwarna coklat } \\
\text { kehitaman, dan berbau khas }\end{array}$ \\
\hline
\end{tabular}

Berdasarkan Gambar 1, dapat dilihat perubahan kadar LDH awal dan kadar LDH akhir. Kadar LDH awal menunjukkan kadar LDH hewan coba sebelum diberikan perlakuan dan kadar LDH akhir menunjukkan kadar LDH hewan coba setelah 30 hari diberi perlakuan. Hasil yang diperoleh menunjukkan terjadi peningkatan kadar enzim LDH sebelum perlakuan yang melebihi batas normal kadar enzim LDH dalam darah pada kelompok 2, kelompok 3 dan kelompok 4 . Hal tersebut dapat dikarenakan hewan coba mengalami keadaan yang memungkinkan peningkatan kadar enzim LDH dalam darah seperti aktivitas fisik yang berlebihan, tekanan darah rendah, aliran darah berkurang akibat respon awal adaptasi hewan coba yang tidak baik (20). Faktor-faktor ini dapat mempengaruhi hasil tetapi tidak berarti bahwa tubuh hewan coba memiliki proses patologis. Sedangkan hasil setelah perlakuan menunjukkan bahwa terjadi penurunan kadar enzim LDH pada kelompok 2, kelompok 3 dan kelompok 4 serta terjadi peningkatan kadar enzim LDH pada kelompok 1 (kontrol negatif) tetapi masih dalam batas normal kadar enzim LDH dalam darah. 
Secara statistik, pada uji 1-Sample Kolmogorov-Sminov, didapatkan bahwa data spesimen darah LDH sebelum dan setelah perlakuan. terdistribusi secara normal artinya data sebelum dan setelah perlakuan dapat digunakan untuk tahap analisis lanjutan yaitu one-way ANOVA. (lampiran VII). Hal tersebut ditunjukkan dengan nilai 0,847 (p>0.05). Selanjutnya pada uji one-way ANOVA, didapatkan hasil bahwa terdapat perbedaan secara nyata tiap masing-masing perlakuan, dengan nilai signifikansi $0,012(\mathrm{p}<0,05)$.

\begin{tabular}{|c|c|c|c|c|c|}
\hline & \multirow{2}{*}{ Kelompok Perlakuan } & \multirow{2}{*}{ Rep } & \multicolumn{2}{|c|}{ Kadar LDH (U/L) } & \multirow[t]{2}{*}{ Selisih } \\
\hline & & & Hari ke-0 & Hari ke-30 & \\
\hline \multirow{4}{*}{1} & \multirow{3}{*}{ Kontrol negatif (asap rokok) } & 1 & 137 & 248 & 111 \\
\hline & & 2 & 363 & 209 & -154 \\
\hline & & 3 & 196 & 458 & 262 \\
\hline & \multicolumn{2}{|l|}{ Rata-rata \pm SD } & $232 \pm 117.222$ & $305 \pm 133.9291$ & $73 \pm 210.5873^{a}$ \\
\hline \multirow{4}{*}{2} & \multirow{3}{*}{$\begin{array}{l}\text { Kontrol positif (asap rokok + } \\
\text { vitamin C) }\end{array}$} & 1 & 630 & 255 & -375 \\
\hline & & 2 & 504 & 154 & -350 \\
\hline & & 3 & 627 & 320 & -307 \\
\hline & Rata-rata \pm SD & & $587 \pm 71.89576$ & $243 \pm 83.64807$ & $-344 \pm 34.39477^{b}$ \\
\hline \multirow{4}{*}{3} & \multirow{3}{*}{$\begin{array}{c}\text { Asap rokok + ekstrak dosis } \\
70 \mathrm{mg} / 200 \mathrm{gBB}\end{array}$} & 1 & 699 & 159 & -540 \\
\hline & & 2 & 761 & 260 & -501 \\
\hline & & 3 & 592 & 290 & -302 \\
\hline & Rata-rata \pm SD & & $684 \pm 85.49269$ & $236.3 \pm 68.63187$ & $-447.7 \pm 127.6493^{b}$ \\
\hline \multirow{4}{*}{4} & \multirow{3}{*}{$\begin{array}{c}\text { Asap rokok + ekstrak dosis } \\
105 \mathrm{mg} / 200 \mathrm{gBB}\end{array}$} & 1 & 714 & 272 & -442 \\
\hline & & 2 & 391 & 191 & -200 \\
\hline & & 3 & 343 & 197 & -146 \\
\hline & \multicolumn{2}{|l|}{ Rata-rata \pm SD } & $482.7 \pm 201.773$ & $220 \pm 45.13314$ & $-262.7 \pm 157.6367^{b}$ \\
\hline
\end{tabular}

Pada uji lanjutan $L S D$ test, diperoleh hasil bahwa kadar LDH hari ke-30 kelompok 1 (kontrol negatif) dengan kelompok 2 (kontrol positif), kelompok 3 (asap rokok+ekstrak $70 \mathrm{mg} / 200 \mathrm{gBB}$ ) dan kelompok 4 (asap rokok+ekstrak $105 \mathrm{mg} / 200 \mathrm{gBB})$ memiliki perbedaan yang signifikan $(\mathrm{P}<0,05)$. Hal ini menandakan bahwa terdapat perbedaan kadar enzim LDH secara nyata pada tikus yang diberi asap rokok+vitamin $C$, pada tikus yang diberi asap rokok+ekstrak temu putih dosis $70 \mathrm{mg} / 200 \mathrm{gBB}$ dan dosis $105 \mathrm{mg} / 200 \mathrm{gBB}$ dengan tikus yang hanya diberi asap rokok saja. Hal ini didukung dengan penelitian yang dilakukan oleh Anbarasi et al (2005) bahwa pemaparan asap rokok pada hewan coba tikus sebanyak 8-10 batang perhari dapat meningkatkan kadar enzim LDH dalam darah (12).

Berdasarkan hasil tersebut diketahui bahwa Pemberian ekstrak temu putih dengan dosis $70 \mathrm{mg} / 200 \mathrm{gBB}$ dan dosis $105 \mathrm{mg} / 200 \mathrm{gBB}$ optimal dalam mengatasi kerusakan atau kematian sel akibat paparan asap rokok.

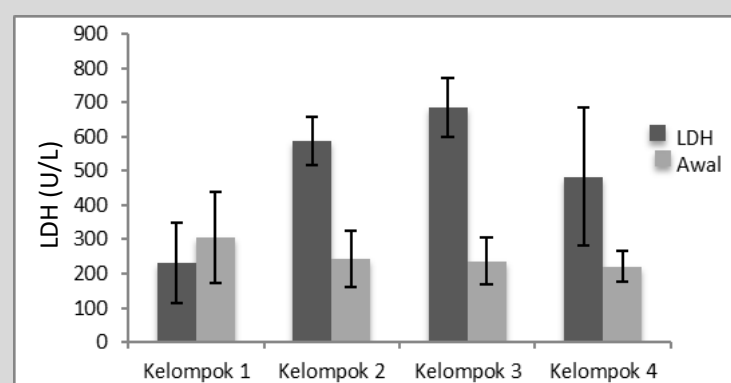

$$
\text { Perlakuan }
$$

Gambar 1. Profil perubahan rata-rata $\pm S D$ kadar enzim aktat dehidrogenase (LDH) pada hewan coba tikus sebelum dan setelah pemberian perlakuan. Keterangan: Kelompok 1: Kontrol negatif, Kelompok 2: Kontrol positif, Kelompok 3: Asap rokok + ekstrak dosis $70 \mathrm{mg} / 200 \mathrm{gBB}$, Kelompok 4: Asap rokok + ekstrak dosis 105 $\mathrm{mg} / 200 \mathrm{gBB}$

\section{KESIMPULAN}

Berdasarkan penelitian yang telah dilakukan, dapat disimpulkan bahwa Pemberian ekstrak temu putih dengan dosis $70 \mathrm{mg} / 200 \mathrm{gBB}$ dan $105 \mathrm{mg} / 200 \mathrm{gBB}$ optimal atau memberikan efek terapi dengan menurunkan kadar enzim LDH darah dengan mengatasi kerusakan atau kematian sel pada tikus yang diberi induksi asap rokok.

\section{DAFTAR PUSTAKA}

1. Shamoon, R. P. 2010. Serum Lactic Dehydrogenase ( LDH ) Activity in Lymphomas: Prognostic Significance and Relationship to Presentation, Stage and Histologic Type, 14(1)

2. Valvona, C. J. et al. 2015. The Regulation and Function of Lactate Dehydrogenase A: Therapeutic Potential in Brain Tumor. doi: 10.1111/bpa.12299.

3. Gk, A. et al. 2017. Clinical \& Medical Biochemistry: Open Access Effects of Lactate Dehydrogenase ( LDH ) in Preeclampsia. 3(1), pp. 1-6. doi: 10.4172/2471-2663.1000129

4. Lott JA, N. E. 1987. Lactate dehydrogenase. Clinical E. a case oriented approach

5. Moss DW, H. A. 1986. Enzymes. Tietz Text. Philadelphia: Saunders Co.

6. RISKESDAS, 2013. Riset kesehatan dasar. Jakarta: Balitbang Kemenkes Ri.

7. Food, U. and Administration, D. 2012. Harmful and potentially harmful constituents in tobacco products and tobacco smoke. established list. Available.at:http://www.fda.gov/downloads/tobaccoProducts/Guidanc eComplianceRegulatoryInformation/UCM297981.pdf.

8. Rodgman, A. \& Perfetti, T.A., 2009 The Chemical Components of Tobacco And Tobacco Smoke, United States of America: CRC Press, Taylor \& Francis Group.

9. Andreoli, C., D, Cigante, D. and Nunziata, A. 2003. 'Areview of in vitro methods to assess the biological activity of tobacco smoke with the aim of reducing the toxicity of smoke. Toxicol In Vitro, 17(5-6), pp. 587-594.

10. Richter, P. et al. 2010. Cytotoxicity of eight cigarette smoke condesates in three test systems, Comparisons between assays and condensates. Regul Toxicol Pharmacol, 58(3), pp. 428-436.

11. Arja, C. et al. 2013. Oxidative stress and antioxidant enzyme activity in South Indian male smokers with chronic obstructive pulmonary disease, Respirology, 18(7), pp. 1069-1075.

12. Anbarasi, K. et al. 2005. Lactate dehydrogenase isoenzyme patterns upon chronic exposure to cigarette smoke : Protective effect of bacoside A', 20, pp. 345-350. doi: 10.1016/j.etap.2005.03.006.

13. Braga, M. E. M. et al. 2003. Comparison of yield, composition, and antioxidant activity of turmeric (Curcuma longa L.) extracts obtained using various techniques. Journal of agricultural and food chemistry, 51(September 2016), pp. 6604-6611. doi: 10.1021/jf0345550. 
14. Sharm, O. P. 1976 Antioxidant activity of curcumin and related compounds, Biochem Pharmacol, 25, pp. 1811-1812.

15. Srimal, R. C., Dhawan, B. N. 1973. Pharmacology of diferuloylmethane (curcumin), a non-steroidal anti inflammatory agent, J. Pharm Pharmacol, 25, pp. 447-452.

16. Saetung, A., Itharat, A. and Dechsukum, C. 2004. Cytotoxic activity of Thai medicinal plants for cancer treatment, (November 2004).

17. Departemen Kesehatan RI, 2008. Farmakope Herbal Indonesia. Edisi I. Jakarta.
18. Murwanti R., Meiyanto E., \& N. A. 2004. Efek Ekstrak Etanol Rimpang Temu Putih (Curcuma zedoaria Rosc.) Terhadap Pertumbuhan Tumor Paru Fase Post Inisiasi Pada Mencit Betina Diinduksi Benzo(a)piren, 15(1), pp. 7-12.

19. Sugeng, S.U., Tiono, H. dan Anandaputri, V.N. Pengaruh Pasta Tomat (Solanum lycopersicum) terhadap Diameter Tubulus Seminiferus Mencit (Mus musculus) Galur DDY yang Terpajan Asap Rokok Berfilter. JKM. 2010;10(1):47-54.

20. Sacher, R. and Richard, 2004. Tinjauan Klinis Hasil Pemeriksaan Laboratorium. Jakarta: EGC. 